\title{
Prospects and Challenges to Arms Control in South Asia
}

\author{
Dr. Muhammad Naveed Qaisar*
}

\begin{abstract}
In recent past, India attempts to modernize its arm forces. The technological advancement in conventional precision strike together with perception of increasing advantage of offensive weapons has led to precarious Indo-Pakistan stability. As a consequence, the latter has reciprocated by increasing existing number of nuclear weapons and delivery means. The above mentioned technological and political developments have increasingly become risky with incentives to launch a first strike. As a result, security dilemma is increasing which may led to war. For ensuring deterrence stability it is imperative that both sides place certain limits on the offensive nature of their weapons system.
\end{abstract}

Key words: India and Pakistan, Security dilemma, Anti-ballistic missile defense, tactical nuclear weapons, offense and defense, arms control.

This Article can be cited as:

Qaisar M N., (2020). Prospects and Challenges to Arms Control in South Asia, Journal of Arts and Social Sciences. VII (2), 11-23.

* Correspondence concerning this article should be addressed to Dr. Muhammad Naveed Qaisar, Assistant Professor, Department of Defense and Strategic Studies, Quaid-e-Azam University, Islamabad, nmagsi@ hotmail.com. 


\section{Introduction}

From the last two decade, India is modernizing its arm forces (Ladwig iii, 2015). Besides, it is shifting its military doctrine from defensive to proactive offensive (Ahmad, 2012). It is also considering to change its nuclear doctrine from no first use to first use option (Clary \& Narang, 2018/19). Side by side, it is rigorously trying to develop effective anti-ballistic missile defense shield (Rajaraman, 2014). It is making such development on the pretext of countering asymmetric threats from Pakistan and also from China. Moreover, Pakistan countering such challenges by increasing number of its nuclear weapons (Dalton \& Krepon, 2015). It also declares to develop low yield tactical nuclear weapons.

The existing military trends between two states are deriving both sides to dangerous arms race with serious repercussion on deterrence stability. Pakistan perceives that in time of crises, India may attack its nuclear assets and neutralize its retaliatory strike by its ABM system. Such development constitutes classic security dilemma for Pakistan. Security dilemma could exacerbate when it is difficult to identify offensive and defensive nature of forces. It could also aggravate when offensive forces become dominate over the defensive forces because of technological innovation. Such phenomenon may lead to arms race and even war (Jervis, 1978).

Moreover, international politics characterized with competition, arm race and frequent crises when offense-defense balance shift in favor of offense. Such development led states to adhere with offensive military doctrine. Thus, increasing the possibility of preemptive and preventive strike (Evera, 1984). Now, in contemporary time, the technological advancement in accuracy of intercontinental ballistic missile, antisubmarine warfare, ballistic missile defense system and cyberspace favor offensive forces (Lieber and Press, 2017). Besides, in some cases, it is difficult to distinguish between offensive and defensive nature of existing military technologies like cyber capabilities (Dumbacher, 2018). In the nutshell, such developments are aggravating the security dilemma for Pakistan and India.

Experientially, arms control has proved effective when it is easier to distinguish between offensive and defensive capabilities. Incentives for arms control enhanced when effectiveness of offensive weapons have advantage over the defensive weapons. As offensive capabilities of both sides threatened each other (Glaser, 1992).

The persistent political hostilities between India and Pakistan has added the possibility of the use of nuclear weapons in next war. India's increasing investment in modernizing its arms forces may promote confidence to its senior political and military leadership to take initiative against Pakistan on occurring of any terrorist's incident inside former territory. A rich discourse on arms control evolve in 1950s and 1960s which posits that reduction in nuclear weapons could not necessarily limit the outbreak of nuclear war but increase second strike capability. In other words, reduce incentive to first strike by reducing the number of nuclear weapons (Chakma, 2010). When ABM technologies were introduced in 1970s, both super powers kept mutual vulnerability by introducing ABM treaty. Thus, assuring deterrence stability till 2002 (Sharikov, 2018). As in case of India and Pakistan, strategic stability is becoming less stable when both sides are reformulating their conventional and nuclear war fighting strategies.

However, there are complication in seeking any effective arm control treaty between India and Pakistan as South Asia security dynamics are closely linked with global security dynamics. A quasi arm race is gaining momentum between US - Russia and US - China. Existing strategic trends among these states indicate that it is difficult to seek mutual arms control between India and Pakistan. Nonetheless, the increasing power of offensive weapons generated fresh avenues to seek meaningful arms control measure between two rivals.

The first part of this paper would briefly analyze about India's buildup of its arm forces including the new Cold Start military doctrine, missile defense shield and its attempt to pursue counterforce options. The second portion would discuss Pakistan's nuclear weapons program including decision to develop 
tactical nuclear weapons. The third aspect would explore increasing security dilemma between the two nuclear states because of introduction of offensive technologies in their force inventories. Finally, the last segment will review prospects of arms control between India and Pakistan.

\section{India-Pakistan Weapon Modernization Program}

Pakistan-India relations are characterized by hostility, mistrust and mutual threat perception. Aside, since the last couple of years, India is aspiring to become a great power. For attaining such a status, it is modernizing its arms forces (Military Balance, 2016). Due to high economic growth since the last two decades, it has requisite resources to invest heavily in "spy satellites, reconnaissance aircraft, drones, early warning radars and electronic intelligence." It is also expected that in future it would significantly invest in nuclear weapons, missile, submarine, intelligence, stealth, cyber war, and satellites.

Since 1997, India's defense expenditure has enhanced with an average of 6.3 percent per year. Having emerged as the biggest importer of defense equipment in 2016 and is planning to spend about $\$ 100$ billion in coming decade on its armed forces modernization program (Ladwig iii, 2015). Besides, it has entered into the list of those few countries with the capacity to design, build and operate nuclear submarine with ballistic missile since 2014. Further, Pakistan is apprehensive that such an ambitious modernization program could adversely affect the existing power balance between the two states. According to former assistant secretary of defense, Peter Lavoy, "India's military modernization program has led to a growing disparity between the Indian and Pakistani conventional military capabilities" the consequences of which "will be either a regional arms race....and/or a lowering of the nuclear threshold...." (Military balance, 2017).

Under the shadow of nuclear weapons, stability-instability paradox underscores to deter major conflict while the incentive to sponsor sub-conventional conflict increases (Montgomery and Edelman, 2015). Some scholar has also reasoned that since overt nuclearization of India and Pakistan, the latter has catalyzed proxy war against the former and repeatedly challenged the relative stronger forces of India (Paul, 2006).

In order to counter such challenges, way back in 2000, then Indian defense minister George Fernandes posited the possibility of limited war below the nuclear threshold (Kumar, 2009). Meanwhile, the military stand-off in 2001-2 and India's inability to effect respond against Pakistan because of allege support to militants has revealed limitations in former previous military thinking (Sunderji Doctrine). Soon thereafter, in April 2004, India came up with a new limited war doctrine labelled "Cold Start" with an objective to quickly mobilize its forces in retaliation to allege Pakistan's "Proxy war". More precisely, India is interested in consummating a quick military victory against Pakistan in any future conflict through execution of such doctrine (Ladwig III, 2007/8).

The aforesaid, Indian Cold start doctrine has three manifest objectives, "inflict significant attrition on enemy forces, retain Pakistani territory for use as a post-colonial bargaining chip, and, by limiting the depth of Indian incursions, avoid triggering a Pakistani nuclear response." (Ahmad, 2012). India's "Sunderji Doctrine" had stated that "If conventional hostilities become inevitable, Indian conventional counter offensives against Pakistan should be modulated in scope Pakistan resorts to the use of nuclear weapons." It emphasized over the counteroffensive dimension, while Cold Start is essentially proactive offensive (Ahmad, 2012).

India, in addition, conceives to use its conventional forces in a limited war with an objective to execute a deep thrust inside Pakistan's territory under nuclear umbrella. Also, it demanded quick mobilization through thrust of armored forces including use of helicopters. More precisely, it called for state of the art intelligent to target Pakistan's nuclear and conventional forces. This explain, India heavy investment into satellites, radars, signals intelligence and reconnaissance technologies (Bracken, 2012). 
In the words of S. Paul Kapur, "Within 72-96 hours of a mobilization order, the Indians plan to drive six to eight brigade- and division-sized armor and infantry units 15-20 Kilometers into Pakistan, seizing a long, shallow swath of territory. The Indians will seek to inflict significant attrition on enemy forces, to retain Pakistan territory for use as post conflict bargaining chip.” (Kapur, 2009).

This new limited doctrine has promulgated Pakistan to go for an arms race (Kapur, 2009). For countering India's Cold Start, in 2011, it announced testing of short-range ballistic missile for carrying out tactical nuclear weapons (Rajaraman, 2014). Pakistan also maintains that in case of any incursion by India, it would most likely use nuclear weapons. It is also assessing that India would not retaliate as long as such weapons would be used in Pakistan's territory. As stated by Walter Ladwig, "Limited war on the subcontinent poses a serious risk of escalation based on a number of factors that are not necessarily under the control of the policymakers or military leaders who would initiate the conflict. A history of misperception, poor intelligence, and India's awkward national security decision-making system suggests that Cold start could be a risky undertaking that may increase instability in South Asia." (Cirincione, 2013).

General Kidwai (retd), former director general of Strategic Plan Division, (SPD) has underlined certain conditions under which Pakistan would resort to use its nuclear weapons: "If India attack Pakistan and conquers a large part of its territory; If India destroyed significant part of Pakistan's military forces; if India blockaded Pakistan; or if India tried to destabilize Pakistan politically." (Cirincione, 2013). Thus, the possibility of potential nuclear war in South Asia can't be ruled out in near future, if these conditions are flouted by India.

Pakistan, on its parts, believes that though deterrence exists at strategic level but the possibility of limited war can't be ruled out and its decision to develop tactical nuclear weapons would assure stability at all level (Ahmed, 2017).

But on other hand, since 2005, India's plans on pursuing to develop anti-ballistic missile defense system. It conducted first ABM test in November 2006 in which Prithvi Air Defense (PAD) followed by successfully interception about $50 \mathrm{Km}$ above the surface. In a related development, in December 2007, a hypersonic missile successfully intercepted other missile about $15 \mathrm{Km}$ above the surface with the name advance air defense system (AAD). Moreover, AAD is designed to intercept up to $30 \mathrm{~km}$ while PAD is meant to intercept its target 5 o to $80 \mathrm{Km}$. In addition, again in March 2009, a ship launched Dhanuch missile with a range of $1500 \mathrm{Km}$ war successfully targeted by PAD at an altitude of $75 \mathrm{Km}$. According to DG, DRDO, V.K. Saraswat, India is endeavoring to "develop a robust anti-missile defense system that will have high-speed interceptions for engaging ballistic missiles in $5000 \mathrm{Km}$ class and above." (Rajaraman 2014).

Having conducted about 10 ABM tests till March 2017, the latest one, successfully intercepted incoming missile in indo and exo-atmosphere which an Indian official claimed "all the mission objectives were successfully met. The weapon system radars tracked the target and provided the initial guidance to the interceptor and destroy it in the endo-atmospheric layer". Another official proudly claimed, "India has crossed an important milestone in building its overall capability towards enhanced security against incoming ballistic missile threats." (Khan, 2012).

It announced in 2012 to deploy anti-ballistic missile defense shield in two of its most important cities, Delhi and Mumbai. Meanwhile, it is cautioned that such development may lead to strategic instability. For working of mutual deterrence, it is significant that major cities of both states remain vulnerable to nuclear strikes. If India gives impression that it is protecting major cities than Pakistan would convincingly increase its nuclear arsenal in order to make the deterrence credible. Such development would also delay any such future negotiation on fissile material cut-off treaty and hence encourage arms race. India also maintained that such program is important because nuclear weapons enabled Pakistan to employ asymmetric war against it (Ganguly, 2014).

In countering such likely threats Pakistan is relying more on its nuclear weapons and is not only increasing numbers but also producing low yield, limited range, battlefield nuclear weapons. Former 
Director General Strategic Plan Division Lt. Gen. Khalid Kudwai justified presence of tactical nuclear weapons in 2015 in following words, "specifically, was born out of a compulsion of this thing that I mentioned about some people on the other side (India) toying with the Idea of finding space for conventional war, despite Pakistan nuclear weapon.... I strongly believe that by introducing the variety of tactical nuclear weapons in Pakistan's inventory, and in the strategic stability debate, we have blocked the avenues for serious military operations by the other side." In 2015, Pakistan's foreign secretary also reiterated about the existence of low yield battlefield nuclear weapons (Kristensen \& Norris, 2016).

Pakistan decision to develop tactical nuclear weapons is causing considerable concerns in the U.S. due to warhead security and lowering the nuclear threshold. The U.S. state department mentioned in 2016, "We have been very concerned about Pakistan's deployment of battlefield nuclear weapons. Battlefield nuclear weapons, by their very nature, pose a security threat because you' re taking battlefield nuclear weapons to the field where, as you know, as a necessity, they cannot be made as secure. So, we're really quite concerned about this and we have made our concern known, and we will continue to press them about what we consider to be the destabilizing aspects of their battlefield nuclear weapons program." (Kristensen \& Norris, 2016). Indian Professor, Rajaraman, also highlighted the destabilizing nature of tactical nuclear weapons, as in the time of crises, because of their necessity they will be less centralized (Rajaraman, 2014).

According to one estimation, currently, Pakistan fissile material production facilities are expanding. Peter Lavoy, then US intelligence officer for South Asia also noted with concern in 2008 that Pakistan is increasing its nuclear weapons with fastest rate than any other country of the world (Kristensen, 2018). It is also estimated that Pakistan would have a stock of 220-250 nuclear weapons by 2025 and if the current trend continued, it going to be the fifth largest nuclear weapon state by that time (Kristensen \& Norris, 2016).

Pakistan perceived that during the time of crises, India may attack Pakistan's nuclear assets and absorb Pakistan's retaliatory strike through its anti-ballistic missile defense shield. These developments constitute a classic security dilemma for Pakistan: India's anti-ballistic defense shield would undermine its first strike capability while India assuring it purely defensive. Besides, Pakistan is concerning that India is entangling on serious efforts to develop multiple independent- targetable- reentry viehicle (MIRVs) to achieve first strike capability (Ganguly, 2014). Moreover, it is also trying to develop counterforce options against Pakistan which is result of strategic paralysis following Pakistan decision to develop battle field nuclear weapons. Notably, Christopher Clary and Vipin Narang explained that India's policy of nuclear restraint is less certain. It is enduring to develop capabilities together with political statements to have preemptive counterforce strike against Pakistan. Contrarily, such developments are inconsistent with India's adhered policy of minimum deterrence (Clary \& Narang, 2018/19).

\section{Enhanced Security Dilemma}

Robert Jervis holds that security dilemma can be intensified when it became easier to conquer than defense and when it became difficult to distinguish between offensive and defensive forces. Such factor increases security dilemma which may lead to arms race and war (Jerivs, 1978).

Likewise, offense-defense theory states that strategic competition become more intensified when when offense become dominant over defense. Similarly, when defense dominants offense more cooperation will be prevailed (Jervis, 1978). Offense-defense balance shift due to technological innovation in defensive or offensive technologies (Lynn-Jones, 1995). However, technological innovation in contemporary strategic landscape has shifted offense-defense balance in favor of offense (Lieber \&Press, 2017). In such scenario states opt offensive military doctrine with strong tendency of arms buildup and such factors increases the possibility of war (Lynn-Jones, 1995).

More generally, the offensive and unilateral military policies are perceived competitive moreover, defensive and bilateral military policies are taken as cooperative (Glaser, 1992). Nuclear deterrence is regarded as defensive, however, forces designed to undermine it is considered as offensive. Offensive 
strategic forces included counterforce capabilities such as accurate intercontinental ballistic missile, antisubmarine warfare and BMDs (Evera, 1998/99).

Before the WWI growing lethality of arms were taken into account by the armed forces. Added to this, the technological development which complicated the problem. The improvement in range and accuracy of weapons together with the employment of railway to transport soldiers in the battlefield led military strategist to contest whether these developments favored defense or offense. Most of the military experts claimed that such development favored attack. To get desired objectives, states tried to achieve superiority of fire power, with increasing range and accuracy (Howard, 1943). Thus, European strategist firmly held that attacker would have advantage in war and believed that warfare would be short and decisive. Therefore from 1902 to 1913 nearly all the European states adopted offensive military doctrine (Evera, 1998).

Professor Scot D. Sagan, opines, offensive military doctrine create instability and is the major cause of WWI. In addition, security dilemma increases when states adopt offensive military doctrine (Sagan, 2009). On the other hand, some writers_argued that there is general perception that cyberspace favors the offense, however, any such advantage depends upon the nature of the goals and capacity of the defender. Moreover, difficulty in recognizing offensive and defensive nature of cyber capabilities also exaggerate the security dilemma. Despite the fact that states are guided by primarily defensive interests, however, increase in such capabilities enhanced other's threat perceptions (Slayton, 2016/17).

Experientially, Arms control have proved fruitful when it became easy to distinguish between offensive and defensive nature of weapons. Hence, it promotes security of both states. Thereby, both the states remain confident that other is not building further arms to offset their defense. So, it reduces misperception about the opponent's intentions. Advantage of arms control increases when benefits of offense grows: sometime it become more costly to defeat adversary's offense with defense and sometime it become beyond the defender means. It has great political benefits since the defender offense also poses threat to the adversary. ABM treaty between the US and then Soviet Union was good example as the retaliatory capabilities had a clear advantage over the damage limitation or offensive capabilities (Glaser, 1992).

Arms control has inherent disadvantage as sometime the adversary may misperceive the defender resolve. In order to demonstrate its resolve, the defender must conduct robust negotiation and avoid uncompensated concessions. For success of arms control, it is imperative that the defender must pursue an offensive policy in order to trade adversary offensive capabilities and convince its opponent that arms race will reduce its security. Even if arms control fails, the defender would pose an offensive threat to adversary (Glaser, 1992).

\section{Prospects and Challenges to Arms Control in South Asia}

It is expected that nuclear weapons could be used in next India-Pakistan war (Caranza, 2017). As Cold War rival the U.S. and Soviet Union reduced about 70 percent of their nuclear arsenals while India and Pakistan have just begun second nuclear arms race in the start of twenty first-century. Meanwhile, Pakistan has accelerated the size of its nuclear arsenal for countering the preponderant conventional strength of India (Korb \& Rothman, 2012). While India's growing investment in modernizing its armed forces together with increasing tension with Pakistan are a matter of concern. The key strategic choice before Pakistan is: Whether to become signatory of unilateral arms control treaties or not. Arms control treaties among belligerent states can promote peace, transparency and prevent sudden war. Reevaluation of arms control treaties is important for several reasons. First, the existence of hostile relationship between India and Pakistan may escalate any conventional conflict to a nuclear war. Second, India's increasing investment in revamping its armed forces may add confidence to its senior military leadership to undertake initiative against Pakistan under pretext of any terrorist incidence inside India. 
In existing international political environment, arms control is pursued with the objectives of limiting damages in case of eruption of war between adversaries and reducing economic cost of defense. Moreover, a rich discourse on arms control has emerged during the 1950s and 1960s, which stipulated that reduction in arms could not necessarily prevent the outbreak of war. In other words, it increases "second strike" capability and reduce first strike capability by limiting the number of strategic nuclear weapons. Therefore, the common interests in avoiding nuclear catastrophe between the two antagonists, it is closely associated with nuclear deterrence (Chakma, 2010). Notably, when in 1970s anti-ballistic missile technologies were introduced, instead of getting into arms race the Cold War rival states agreed to keep mutual vulnerabilities by introducing ABM treaty. Thus, assuring strategic stability until 2002 (Sharikov, 2018).

The existence of enduring rivalries between India and Pakistan due to convoluted history of communal violence coupled with geographical proximity and complex territorial dispute on Jammu and Kashmir have repeatedly led to war and crises. Therefore, there are compelling reasons for arms control in South Asia. Moreover, since the overt nuclearization of India and Pakistan in (May, 1998) both states fought a limited war in 1999 in Kargil mountainous height. Again in 2001-002 the armies of both stood eyeball to eyeball for nearly ten months. With relations again turning tense in 2008 for allege Pakistan's support to terrorists' incident in Mumbai (in 2008). Recurrence of such serious incident have continued sporadically (Chakma, 2010). The recent Pulwama attack also indicate that there is flashpoint danger of potential nuclear confrontation between the two states.

Nevertheless, the realist believes that for preventing nuclear war, it is important to achieve stable deterrence between the two antagonists. Achieving such goal is becoming murky when Pakistan is reforming its nuclear doctrine while India is shifting its conventional and nuclear war fighting strategies. It is perceived that India maintain "recessed deterrence posture" in time of peace with warheads not fully mated. Many scholars consider that recessed deterrence promote strategic stability. However, since 2001 and 2002 India-Pakistan formulated their nuclear doctrine driven by ready to use nuclear weapons. Thus, fomenting crises instability. Professor Viping Narang opines "is largely now a myth .....it seems likely that all of India's nuclear missile system will eventually be deployed in a near ready 'canisterized' state, which is a far cry from the prevailing perception that India maintains its nuclear force in a relatively recessed state.", Since 2001, in addition the U.S. also believed that Pakistan could "probably assemble some nuclear weapons fairly quickly." Because of these developments, now it's too difficult to maintain recessed deterrence in the absence of any arms control agreement between two states (Caranza, 2017).

Presently, there is no arms control regime between India and Pakistan to promote strategic stability, avoid escalation at nuclear level and prevent war (Khan, 2016).

Arms control approaches have significantly diversified after the ending of Cold War and shifted from complicated discussion between the US and Soviet Union towards measure that can be executed quickly. Moreover, in contemporary strategic environment informal CBMs are accorded more consideration.

India and Pakistan can stuck down their nuclear arms race by negotiating nuclear CBMs and threat reduction measures (TRMs). The most salient CBMs between India and Pakistan is the existence of hotline line between Director General of Military operations. Yet, such CBMs do not mean more when crises are deliberatively contrived and promoted.

Three CBMs/TRMs have taken place between the two countries. Both states agreed in 1985 not to attack each other designated nuclear installation and facilities. Signed in 1988 and ratified in January 1991, this agreement also included exchange of information on the "latitude and longitude of its nuclear installations and facilities and whenever there is any change." Another important CBMs signed in April 1991 included "Advance Notice on Military Exercise, Manoeuvers and Troop Movements and the Agreement on Prevention of Air Space Violations and Permitting Overflights and Landing by Military Aircraft." 
India and Pakistan opted to sign a number of CBMs and arms control initiative which can be sequenced as following:

- $\quad$ "Agreement on the Prohibition of Attack against Nuclear Installations and Facilities singed on December 31, 1988.

- $\quad$ Agreement on Advance Notification of Military Exercise, Maneuvers and Troops Movements, signed on April 6, 1991.

- $\quad$ Agreement on Prevention of Airspace Vioaltions and for Permitting Overflights and Landings by Military Aircrafts, signed on April 6, 1991.

- Joint Declaration on the Complete Prohibition of Chemical Weapons on August 19, 1992.

- An Agreement on Advance Notification of Ballistic Missile Tests, signed on October 3, 2005.

- An Agreement on Reducing the Risk from Accidents Relating to Nuclear Weapons, signed on Februaru 21, 2007." (Chakma, 2010).

Some other measures were also undertaken for reducing military tension like Lahore Declaration signed in Feb. 1999 which was interrupted during Kargil crisis. Again, peace process was resumed in 2004 under the name with composite dialogue but it again disrupted following the November 2008 Mumbai attack. Policy makers are skeptical that these measures are not enough to prevent any future nuclear confrontation between India and Pakistan. As Prof. Bhumitra Chakma darkly notes, "New Dehli and Islamabad have thus far undertaken very limited measures in establishing crisis stability to forestall a future crisis from going out of control despite the fact that they confronted several crises over the past decade under the nuclear shadow."

There are doubts about the effectiveness of these CBMs, as both sides accuse each other of not disclosing all the information regarding their nuclear installation what their 1988 agreement demands. Similarly, both sides also accuse each other on the sincerity of advance notification on ballistic missile testing of 2005 (Chakma, 2010). Arms control is effective and is enhanced by some kind of political compromise and accommodation. As Colin Gray explained, "So long as political rivalry and hostility are not abated there can be no sufficient basis for an arms control process to accomplish anything more substantial than registration of the facts of military competition." (Gray, 1984). Likewise, Rodney Jones writes that, "An arms control measure or agreement must, by definition, perform one or more of several possible functions, including limiting or constraining the subject government's production (or acquisition), deployment, location, or use of weapons systems, or related military forces, in defined ways." (Jones, 2005). On her part, Maria Rublee, explains that "arms control focuses on restraint of weapons through policy, looking at numbers, types, development, and use." Finally, but not least, Larsen notes that "arms control could lead to an increase in a certain type of weapons if parties agreed that this would enhance stability and reduce the possibility of war." (Rublee, 2017).

Thus, India and Pakistan political rivalry has shrunk its limited pace for arms control between two states. For effectively managing nuclear risks, it is important to continue peace process with India in letter and spirit. Unfortunately, time and time again, such process has been disrupted by terrorists' attacks. Therefore, some of the Indian scholar have proposed to continue such process by delinking it from terrorism (Sarkar, 2017).

Allegedly, Pakistan's strategy of abetting extremism against India in Kashmir has added a new and dangerous dimension to their already fragile relations. In reaction, India's offensive military doctrine and Pakistan's determination to use low yield tactical nuclear weapons have further complicated the strategic relations between two states (Biswas, 2017). There is a strong possibility that such weapons would be used by the hawkish element by either side when faced with existential threat. Resort to such weapons would violate the historical taboo over the use of nuclear weapons which has been established since use on Hiroshima and Nagasaki (Rajaraman, 2014). New Delhi exercised strong restraint after Mumbai attacks in 
2008, while there is no guarantee that it would be circumspect in any other such incident under Modi government (Korb \& Rothman, 2012). Moreover, there is very real possibility of limited nuclear exchange. Therefore, there should be a mechanism to prevent rapid escalation from conventional to nuclear war (Akhtar, 2017). Nonetheless, the development of tactical nuclear weapons and increasing fissile material stockpile by Pakistan give an incentive to India to negotiate serious bilateral nuclear arms control treaty with Pakistan (Donnell, 2017).

\section{Why arms control tended to fail?}

As long as India and Pakistan perceive deficiency in conventional and nuclear capabilities neither side would be seriously interested in negotiating arms control (Jones, 2005).

A writer highlighted the lack of the interests of policy makers in arms control in South Asia as nuclear programs of both states are in nascent phase. Both states are engaged in force building and therefore arms build-up is a dominant trend in their strategic relationship. Meanwhile, both have yet to underscore assured second-strike-capability and arms control seems an impediment to force building objectives. Other reasons for lack of the interests in arms control is the existence of toxic political relations and south Asia security dynamics linkages with extra-regional powers. Under such conditions probability of reaching arms control is bleak. India justifies its nuclear program vis-a-vis China, while China's strategic posture is tied to the U.S. In the words of Prof. Chakma, "The South Asian security dilemma, therefore, is linked to the systemic security dilemma." (Chakma, 2010). As mentioned, extra-regional links of India and Pakistan security dilemma are creating hindrances in prospect of any arms control between them (Chakma, 2010).

\section{Big power Factor}

George W. Bush administration considered arms control as dangerous and destabilizing, if it would put any limit on development, stockpiling or any other capability for the US as it needed in order to secure itself against potential threat from its competitors and asymmetric threats. It also affirmed that the US would pursue BMD and precision strike potential capabilities (Gallagher, 2015).

Some of the writer also claim that changes in U.S. arms control policy would definitely help IndiaPakistan to move beyond the agreement on pre-notification of ballistic missile test (1999) and agreement not to attack each others nuclear facilities. They also argue that when U.S. and China would ratify CTBT, then India would be compel to do the same and then Pakistan would likely do it (Rublee, 2017). Some of the writers have also suggested that if the U.S. needs to review its existing nuclear policy and start negotiating on no-first-use policy with France, Britain, Russia and China. Later, the other de facto nuclear weapons states-(India, Pakistan and Israel) if arrived at, can be persuaded to declare no first use policy. Such multilateral agreement which pledges not to be the first to use nuclear weapons in a war would significantly reduce the likelihood of India and Pakistan tensions from spinning out of control (Korb \& Rothman, 2012).

Notwithstanding, the prospects of arms control at international level as bleak, there were high expectation in president Obama inspirational speech delivered in March 2009 in Prague. But such hopes began to evaporate after 2010 when most of the nuclear armed states evinced skepticism on Obama's Prague agenda. More particularly, within the US, some of the hawkish element in department of defense and nuclear establishment were committed to scuttle president's agenda. Therefore in 2016, Pentagon announced to spend $\$ 1$ trillion on the modernization of nuclear bombs, bombers, missile and submarines. In the legacy of President Obama Prague agenda, the U.S. also contemplated declaring no-first-use policy. But such move was fiercely resisted by the U.S. allies in Europe and Pacific. Thus the U.S. dropped this idea of no first use (Thakur, 2017).

In December 2016, the U.S. Defense Science Board persuaded the Trump administration to develop low-yield nuclear weapons which provide "tailored nuclear option for limited use." President Trump promised to "greatly strengthen and expand (U.S.) nuclear capability." In February, he observed 
that the U.S would stay at the "Top of the (nuclear) pack" these statements were reinforced when air force general Paul Selva, Vice Chairman of the Joint Chiefs of Staff focused on the development of smaller and low-yield, useable nuclear weapons (Thakur, 2017).

The U.S. Nuclear Posture Review (2018) suggests that current global strategic environment is defined by uncertainty and posits a serious challenge to future arms control. It also highlighted Russian aggression, non-compliance and modernization of weapons and suggested that the U.S. must adhere to a policy of "peace through strength" and demanded diversification of U.S. capabilities (Williams, 2018).

The former U.S. secretary of state, Jim Mattis while referring to NPR 2018 remarked that "Yet we must recognize that the current strategic environment makes it difficult to progress toward nuclear arms reductions in the near term extremely challenging. Ensuring our nuclear deterrent remains strong will provide the best opportunity for convincing other nuclear deterrent remains strong will provide the best opportunity for convincing other nuclear powers to engage in meaningful arms control initiatives." (Nuclear Posture Review, 2018.).

Moreover, the NPR 2018, reveal the possibility of use of nuclear weapons in case of cyber-attack on command and control, and space-based assets which denote that non-nuclear threats also has an impact on the U.S. capabilities. The NPR 2018 regarding arms control argues that "further progress is difficult to envision" because of a combination of alleged Russian violation of existing treaties and geopolitical uncertainty.

Under existing strategic condition nearly all nuclear armed nations are modernizing existing stocks of nuclear weapons. In the prevailing scenario, Russia and the U.S are least interested in any further attempts at disarmament. Both sides have demonstrated divergent nuclear priorities over the past several years and are opting nuclear strategy and posture which increases the risk of outbreak war between the two.

Russia and the U.S are engaged in massive nuclear modernization efforts with an estimation that next decade the U.S. will spend about $\$ 400$ billion. In competition, Russia is also modernizing its nuclear arsenal from many years. In 2010, President Putin also pledged to modernize nuclear weapons till 2020 at the cost of about $\$ 650$ billion (Anichkina, 2017).

An arms race is getting momentum between the U.S-Russia and between the U.S-China. Whereas, Russia is concerned that the U.S. is not interested in accepting any limit to its BMDs program and its deployed BMDs in Europe (European Phase Adoptive Approach) could also be upgraded. Skeptical of BMDs assets, it could deploy in space and BMDs could not be delinked from strategic offensive forces. In addition, the U.S is not supportive of Russia-China initiative of deploying weapons in space. Moscow is apprehensive about the long-range high precision conventional capabilities, such as the U.S. cruise missile with a cumulative capability to be launched from sea and from air. These trends reveal that there are little prospects of arms control between them in near future. Given these, there is need for urgent actions to prevent dangerous arms race to avoid inadvertent or accidental nuclear escalation (Anichkina, Peczeli \& Roth, 2017).

The above-mentioned trends in great powers are not conducive for India and Pakistan to seek mutual arms control treaty. Yet increasing power of the offensive technologies at both sides generated fresh avenues to pursue meaningful arms control measure to assure mutual deterrence. In short, it is high time for both India and Pakistan to avoid provocative policies and promote cooperation and peace through arms control measures by reducing tension (Glaser, 1992).

\section{Conclusion}

Over the course of history, India and Pakistan fought number of battles and war with each other. Recent, Pulwama attack revealed that India and Pakistan air forces fought against each other after 48 years and in future such situation could go out of control. An arms race is going on in South Asia as both India and Pakistan are rapidly arming themselves. The modernization program of India's armed forces is 
enhancing security dilemma for Pakistan. Hence, it is relying more on its nuclear weapons and therefore, lowering nuclear threshold. On its part, it is increasing production of atom bombs including low yield useable nuclear weapons.

Besides, India's shift towards counterforce policy could not only led to arms race but also dangerous "first-strike instability". The recent technological developments followed by increasing precision strike weapons created a perception among defense analyst for incentive to strike first. Such technological development may not completely favor second strike retaliation. In other words, technological balance is shifting in ways which favor damage limitation and counterforce strategies as the cost of building such forces are falling. Moreover, in future crises like situation there are incentive for both sides to escalate the crises at nuclear level as there are incentive for both sides to massively strike at each other in the beginning of the crises.

Such dangerous trends and perceptions suggest that it is imperative for both India and Pakistan to put certain limits on the offensive nature of their nuclear weapons to ensure deterrence stability.

\section{References}

Ahmed, A. (2012). Cold Start: The Life Cycle of a Doctrine. Comparative Strategy, 31 (5), 453468.

Ahmed, M. (2017). India's Nuclear Exceptionalism: Fissile Materials, Fuel Cycles, and Safeguards. Harvard Kennedy School, Belfer Center. p.45.

Akhtar, R. (2017). Managing nuclear risk in South Asia: A Pakistani response. Bulletin of Atomic Scientist, 73 (1), 62.

Anichkina, T. P., \& Roth, N. (2017). The Future of US-Russia Nuclear Deterrence and Arms Control. Bulletin of the Atomic Scientist, 73 (4), 273.

Biswas, A. (2017). Pakistan's Tactical Nukes: Relevance and Options for India. The Washington Quarterly, 40 (3), 169.

Bracken, P. (2012). The Second Nuclear Age: Strategy, Danger, and the New Power Politics. New York: Times Books Henry Hold and Company, 17-167.

Chari, Prof. P. R. (2005). Strategic Stability in South Asia: The Role of Confidence-Building and Threat Reduction Measures. Contemporary South Asia, 14 (2), 211-213.

Carranza, \& Mario, E. (2017). Managing nuclear risk in South Asia: A US response. Bulletin of Atomic Scientist, 73 (1), 65.

Cirincione, J. (2013). Nuclear Night Mares: Securing the World Before it is too Late. New York: Columbia University Press, 129.

Chakma, B. (2010). Nuclear Arms Control Challenges in South Asia. India Review, 9 (3), 364.

Clary, C., \& Narang, V. (2018/19). India's Counterforce Temptations: Strategic

Dilemmas, Doctrine, and Capabilities. International Security, 43 (3), 8. 
Dalton, Toby., \& Krepon, M. (2015). A Normal Nuclear Pakistan. Carnegie Endowment for International Peace. Washington D.C.

Donnell, \& Frank, O. (2017). Reconsidering minimum deterrence in South Asia: India response to Pakistan's tactical nuclear weapons. Contemorary Security Policy, 38 (1), 96.

Dumbacher, \& Erin, D. (2018). Limiting Cyberwarfare: Applying arms-control models to an emerging technology. The Nonproliferation Review, 1-20,

Evera, S. V. (1998). Offense, Defense and the Causes of war. International Security, 22 (4), 42.

Evera, S. V. (1984). The Cult of the Offensive and the Origin of the First World War. International Security, 9 (1), 58-59.

Evera, S. V. (1998/99). Correspondence: Taking Offense at Offense-Defense Theory. International Security, 23 (3), 195.

Ganguly, S. (2014). India's Pursuit of Ballistic Missile Defense. The Nonproliferation Review, 21 (3-4), 380-374.

Glaser, C. L. (1992). Political Consequences of Military Strategy: Expanding and Refining the Spiral and Deterrence Models. World Politics, 44 (4), 494-538.

Gallagher, N. W. (2015). Re-thinking the Unthinkable: Arms Control in the Twenty-First Century. The Non-Proliferation Review, 22 (3), 470.

Gray, C. S. (1984). Arms Control: Problems in R, James Woolsey, eds., Arms Control: Ethics, Strategy, Politics. San Francisco: ICS Press, 160.

Howard, M. (1986). Men against Fire: The Doctrine of the Offensive in 1914 in Petter Paret, eds., Makers of Modern Strategy. New Jersey: Princeton University Press.

Jervis, R. (1978). Cooperation under Security Dilemma. World Politics, 30 (2), 167-214.

W. Jones, Rodney. (2005). Prospects for Arms Control and Strategic Stability in South Asia. Contemporary South Asia, 14 (2), 198-199.

Khan, Z. (2017). India's Ballistic Missile Defense: Implications for South Asian Deterrence Stability. Washington Quarterly, 40 (3), 188-187.

Kristensen, H. M., \& Robert, S. N. (2016). Pakistani nuclear forces, 2016. Bulleting of Atomic Scientist, 72 (6), 370.

Kumar, A. Vinod. (2009). A Cold Start: India's Response to Pakistan-Aided Low Intenstity Conflict. Strategic Analysis, 33 (3), 325.

Lieber, K. A. \& Daryl, G. P. (2017). New Era of Counter force: Technological Change and the future of Nuclear Deterrence. International Security, 41 (4), 9-49. 
Lynn-Jones, S. M. (1995). Offense-Defense Theory and its Critics. International Security, 4 (4), 668-665.

Ladwig III, W. C. (2007/8). A Cold Start for Hot Wars? The Indian Army's New Limited War Doctrine. International Security 32 (3), 164-158.

Ladwig III, W. C. (2015). Indian Military Modernization and Conventional Deterrence in South Asia. Journal of Strategic Studies, 38 (5), 729-772

Malygina, A., Fickenscher, S. E., \& Nielsen, J. (2017). Amid High Tensions, an Urgent Need for Nuclear Restraint. Bulletin of the Atomic Scientist, 73 (4), 279-280.

Montgomery, E. B., \& Eric, S. E. (2015). Rethinking Stability in South Asia: India, Pakistan, and the Competition for Escalation Dominance. Journal of Strategic Studies, 38 $(1-2), 162$.

Rajaraman, R. (2014). Battlefield Weapons and Missile Defense: Worrisome Development in Nuclear South Asia. Bulletine of the Atomic Scientist, 70 (2), 68.

Sagan, \& Scott, D. (1986). 1914 Revisited: Allies, Offense and Instability. International Security, $11(2), 152-154$.

Sarkar, J. (2017). Managing nuclear risk in South Asia: An Indian response. Bulletin of Atomic Scientist,73 (1), 59 .

Slayton, R. (2016/17). What is the Cyber Offense-Defense Balance? Conception, Causes and Assessment. International Security, 41 (3), 108.

Sharikov, P. (2018). Artificial intelligence, cyberattack, and nuclear weapons-A dangerous combination. Bulletin of Atomic Scientist, 74 (6), 372.

Rublee, Maria. Rost. (2017). India-Pakistan nuclear diplomacy: Constructivism and the prospects for nuclear arms control and disarmament in South Asia. Contemporary Security Policy, $38(3), 487$.

Thakur, R. (2017). The Nuclear Ban Treaty: Recasting a Normative Framework for Disarmament. The Washington Quarterly, 40 (4), 73-74.

Williams, H. (2018). Strategic Stability, Uncertainty and the Future of Arms Control. Survival, 60 (2), 46-47. 